\title{
Asymmetric microbial reduction of ketones: absolute configuration of trans-4-ethyl-1-(1S-hydroxyethyl)cyclohexanol
}

\author{
Cristina Pinedo-Rivilla ${ }^{a}$, Mariana Carrara Cafêu ${ }^{\mathrm{b}}$, Josefina Aleu Casatejada ${ }^{\mathrm{a}}$, Ângela Regina Araujo ${ }^{\mathrm{b}}$, \\ Isidro G. Collado ${ }^{\mathrm{a}, *}$ \\ ${ }^{a}$ Departamento de Química Orgánica, Facultad de Ciencias, Universidad de Cádiz, República Saharaui s/n, Apdo. 40, 11510 Puerto Real, Cádiz, Spain \\ ${ }^{\mathrm{b}}$ Instituto de Química, Universidade Estadual Paulista, CP355, 14801-970 Araraquara, São Paulo, Brazil
}

\section{A R T I C L E I N F O}

\section{Article history:}

Received 14 September 2009

Accepted 2 November 2009

Available online 26 November 2009

\begin{abstract}
A B S T R A C T
A set of five fungal species, Botrytis cinerea, Trichoderma viride and Eutypa lata, and the endophytic fungi Colletotrichum crassipes and Xylaria sp., was used in screening for microbial biocatalysts to detect monooxygenase and alcohol dehydrogenase activities (for the stereoselective reduction of carbonyl compounds). 4-Ethylcyclohexanone and acetophenone were biotransformed by the fungal set. The main reaction pathways involved reduction and hydroxylations at several positions including tertiary carbons. $B$. cinerea was very effective in the bioreduction of both substrates leading to the chiral alcohol (S)-1phenylethanol in up to $90 \%$ enantiomeric excess, and the cis-trans ratio for 4-ethylcyclohexanol was 0:100. trans-4-Ethyl-1-(1S-hydroxyethyl)cyclohexanol, obtained from biotransformation by means of an acyloin-type reaction, is reported here for the first time. The absolute configurations of the compounds trans-4-ethyl-1-(1S-hydroxyethyl)cyclohexanol and 4-(1S- and 4-(1R-hydroxyethyl)cyclohexanone were determined by NMR analysis of the corresponding Mosher's esters.
\end{abstract}

(c) 2009 Elsevier Ltd. All rights reserved.

\section{Introduction}

Interest in integrating traditional organic chemistry and biocatalysis has increased dramatically over the past decade. ${ }^{1}$ Biocatalytic reactions that employ either enzymes or whole cells are well suited for green chemistry because mild conditions are applied in these reactions by lowering the energy requirements; fewer by-products are formed as they are highly chemo-, regio- and stereoselective, and multi-step chemical syntheses can be achieved in just a few steps via biocatalysis. ${ }^{2}$ As a result, biocatalytic processes are often cheaper and more direct than their chemical counterparts. $^{3}$

The use of microorganisms is advantageous because of the growth and easy formation of the multienzymatic system. ${ }^{4}$ One crucial aspect to be considered for a successful microbial biotransformation is the selection of the natural source to be studied. In this work, whole cells from three filamentous fungi and two endophytic fungi were tested as biocatalysts. Endophytic fungi are an unexplored or at least under-explored source for microbial biotransformations. ${ }^{5}$

Therefore, as a part of our research program focusing on the study of the biocatalytic potential of filamentous fungi, we herein report the biotransformation of 4-ethylcyclohexanone $\mathbf{1}$ and aceto-

\footnotetext{
* Corresponding author. Tel.: +34 956 016368; fax: +34956016193.

E-mail address: isidro.gonzalez@uca.es (I.G. Collado).
}

phenone 2, two well-known pro-chiral ketones, by the filamentous fungi Botrytis cinerea, Trichoderma viride and Eutypa lata, and the endophytic microorganisms Colletotrichum crassipes and Xylaria sp., in order to detect monooxygenase and alcohol dehydrogenase activities. $^{6,7}$

\section{Results and discussion}

The selected set of five fungal species mentioned above was used in the screening of microbial biocatalysts to detect monooxygenase and alcohol dehydrogenase activities. The reduction of 4 ethylcyclohexanone $\mathbf{1}$ to 4-ethylcyclohexanol 1a was used as the first reaction in the screening.

\subsection{Biotransformation of 4-ethylcyclohexanone 1}

4-Ethylcyclohexanone 1 was subjected to the action of whole cells of five filamentous fungi, B. cinerea, E. lata, T. viride, C. crassipes and Xylaria sp. to verify the biocatalytic potential of these fungi in the biotransformation of ketones. The results of the biotransformations are presented in Tables 1 (static cultures) and 2 (shaken cultures) in terms of isolated yields and the predominant configurations of the products obtained. Shaken cultures were included in order to observe differences resulting from the degree of oxidation. 
Table 1

Biotransformation of 4-ethylcyclohexanone $\mathbf{1}$ on surface cultures

\begin{tabular}{|c|c|c|c|c|c|c|c|c|c|}
\hline \multirow[t]{2}{*}{ Microorg. } & \multirow[t]{2}{*}{ Time (days) } & \multicolumn{2}{|c|}{ 1a } & \multicolumn{3}{|c|}{$1 b$} & \multirow{2}{*}{$\frac{\text { 1c }}{\text { Yield (\%) }}$} & \multirow{2}{*}{$\begin{array}{l}\text { 1d } \\
\text { Yield (\%) }\end{array}$} & \multirow{2}{*}{$\frac{1 \mathrm{e}}{\text { Yield (\%) }}$} \\
\hline & & Yield (\%) & Ratio cis-trans & Yield (\%) & $\mathrm{ee}^{\mathrm{a}}(\%)$ & Ratio cis-trans & & & \\
\hline \multirow[t]{2}{*}{ B. cinerea } & 5 & 21.4 & $0: 100$ & - & - & - & - & - & - \\
\hline & 10 & 8.1 & $0: 100$ & 3.4 & 42.0 & $0: 100$ & - & - & - \\
\hline \multirow[t]{2}{*}{ T. viride } & 2 & 18.8 & $65: 35$ & - & - & - & 3.4 & - & - \\
\hline & 5 & 51.7 & $65: 35$ & - & - & - & - & - & - \\
\hline \multirow[t]{3}{*}{ E. lata } & 8 & 23.3 & $3: 97$ & - & - & - & 0.3 & - & - \\
\hline & 15 & 45.1 & $3: 97$ & - & - & - & 5.5 & - & - \\
\hline & 20 & 21.8 & $3: 97$ & - & - & - & 6.4 & - & - \\
\hline \multirow[t]{2}{*}{ C. crassipes } & 5 & 3.0 & $0: 100$ & 4.6 & 32.1 & $97: 3$ & - & - & - \\
\hline & 10 & 0.3 & $0: 100$ & 7.2 & 51.4 & $97: 3$ & - & - & 8.5 \\
\hline \multirow[t]{2}{*}{ Xylaria sp. } & 5 & - & - & - & - & - & - & 7.5 & 3.1 \\
\hline & 10 & - & - & - & - & - & - & 4.3 & 4.0 \\
\hline
\end{tabular}

a ee: enantiomeric excess. ee was determined by means of GC analyses.

Table 2

Biotransformation of 4-ethylcyclohexanone $\mathbf{1}$ on shaken cultures

\begin{tabular}{|c|c|c|c|c|c|c|c|c|c|}
\hline \multirow[t]{2}{*}{ Microorg. } & \multirow[t]{2}{*}{ Time (days) } & \multicolumn{2}{|c|}{$1 \mathbf{a}$} & \multicolumn{3}{|c|}{ 1b } & \multirow{2}{*}{$\frac{1 \mathbf{c}}{\text { Yield (\%) }}$} & \multirow{2}{*}{$\begin{array}{l}\text { 1d } \\
\text { Yield (\%) }\end{array}$} & \multirow{2}{*}{$\begin{array}{l}\mathbf{1 e} \\
\text { Yield }(\%)\end{array}$} \\
\hline & & Yield (\%) & Ratio cis-trans & Yield (\%) & $\mathrm{ee}^{\mathrm{a}}(\%)$ & Ratio cis-trans & & & \\
\hline \multirow[t]{2}{*}{ B. cinerea } & 5 & 28.0 & $0: 100$ & 1.3 & 16.2 & $0: 100$ & - & - & - \\
\hline & 10 & 7.3 & $0: 100$ & 11.0 & 56.1 & $0: 100$ & - & - & - \\
\hline \multirow[t]{2}{*}{ T. viride } & 2 & 10.5 & $65: 35$ & - & - & - & - & - & - \\
\hline & 5 & 30.5 & $65: 35$ & - & - & - & - & - & - \\
\hline \multirow[t]{2}{*}{ E. lata } & 8 & 46.4 & $3: 97$ & - & - & - & 4.4 & - & - \\
\hline & 15 & 47.1 & $3: 97$ & - & - & - & 8.0 & - & - \\
\hline \multirow[t]{2}{*}{ C. crassipes } & 5 & 4.0 & $0: 100$ & - & - & - & - & - & 6.5 \\
\hline & 10 & 0.3 & $0: 100$ & - & - & - & - & - & 1.3 \\
\hline \multirow[t]{2}{*}{ Xylaria sp. } & 5 & - & - & - & - & - & - & 2.4 & 9.8 \\
\hline & 10 & - & - & - & - & - & - & 3.3 & 6.5 \\
\hline
\end{tabular}

a ee: enantiomeric excess. ee was determined by means of GC analyses.

Following a period of incubation for each fungus, several biotransformation products 1a-1e were detected. Product structure assignment was done by NMR analysis as described in Section 4 .

4-Ethylcyclohexanone 1 was reduced to the corresponding cisand trans-alcohols ${ }^{8}$ (Scheme 1). As shown in Tables 1 and 2, B. cinerea and $C$. crassipes gave the trans-4-ethylcyclohexanol trans-1a with a cis-trans ratio of $0: 100$, and $E$. lata with a cis-trans ratio of $3: 97$ and a yield of $\sim 47 \%$. cis-alcohol 1a was produced by $T$. viride with a cis-trans ratio of 65:35. Most of the biotransformations occurred with low conversion because several products were formed.<smiles>CC(O)C1CCC(O)CC1</smiles>

$1 \mathbf{b}$

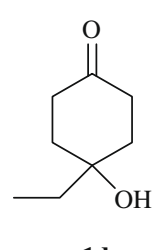

$1 d$<smiles>CC(O)C1CCC(=O)CC1</smiles>

$1 \mathrm{e}$
In addition to the bioreduction of 4-ethylcyclohexanone $1, B$. cinerea and C. crassipes produced 4-(1-hydroxyethyl)cyclohexanol $\mathbf{1 b} .^{9}$ B.

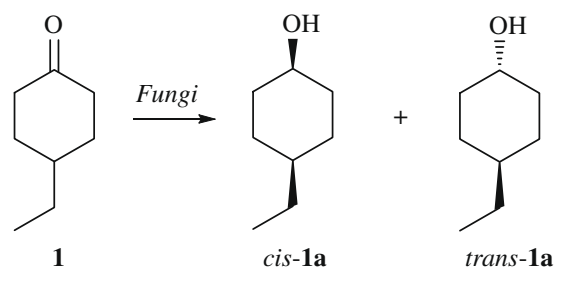

Scheme 1. Reduction of 4-ethylcyclohexanone $\mathbf{1 .}$ cinerea gave the trans-isomer with $56.1 \%$ ee. In contrast, $C$. crassipes afforded the cis-isomer suggesting that the compound cis-4-ethylcyclohexanol cis-1a was hydroxylated by this fungus on the ethyl group.

The stereoselective formation of carbon-carbon bonds is one of the key transformations in synthetic organic chemistry and is gaining increasing attention. Enzymatic systems belonging to the lyase class such as pyruvate decarboxylases are capable of carrying out acyloin-type condensation reactions in water under mild conditions, in turn leading to chiral $\alpha$-hydroxy ketones which are versatile building blocks for the pharmaceutical and chemical industries. In some cases, these $\alpha$-hydroxy ketones are not isolated but an erythro diol is formed instead. ${ }^{10}$

Thus, compound 1c was obtained from biotransformation by $T$. viride and E. lata as a colourless oil with an $\mathrm{M}^{+}$peak at $\mathrm{m} / z 172$ and featuring a ${ }^{13} \mathrm{C}$ NMR spectrum consistent with the molecular formula $\mathrm{C}_{10} \mathrm{H}_{20} \mathrm{O}_{2}$. The ${ }^{1} \mathrm{H}$ NMR spectrum was close to that of 4-ethylcyclohexanol 1a, but the appearance of two signals at 74.6 and $17.1 \mathrm{ppm}$ in the ${ }^{13} \mathrm{C}$ NMR spectrum (C-9 and C-10, respectively) and two signals at 1.15 and $3.52 \mathrm{ppm}$ in the ${ }^{1} \mathrm{H}$ NMR spectrum showed that 1c presented another hydroxylated ethyl group. The trans disposition was deduced from NOE interactions $\mathrm{H}-4 / \mathrm{H}-10$. The absolute configuration at C-9 was determined via the Mosher ester analysis protocol. ${ }^{11}$ In particular, derivatization of $\mathbf{1 c}$ with $(R)$ - and (S)- $\alpha$-methoxy- $\alpha$-phenylacetic (MPA) acids followed by ${ }^{1} \mathrm{H}$ NMR analysis of the resulting diastereomeric esters (S)-MPA1c and $(R)$-MPA-1c revealed a negative $\delta(\delta R-\delta S)$ value for $\mathrm{H}-10$ $(-0.14)$ and positive $\delta(\delta R-\delta S)$ values for $\mathrm{H}-2$ and $\mathrm{H}-4(+0.10$ and +0.46 , respectively). Following MPA rules, these data indicated an $S$-configuration for C-9 in 1c which is consistent with Prelog's rule. $^{12}$ This compound, trans-4-ethyl-1-(1S-hydroxyethyl)cyclohexanol (1c), is reported here for the first time. 
The formation of 1c can be explained assuming the formation of a $\mathrm{C}-\mathrm{C}$ bond by means of an enzyme-type pyruvate decarboxylase leading to a chiral $\alpha$-hydroxy ketone. The two-carbon unit originating from the decarboxylation of pyruvate is transferred to the ketone substrate. Presumably, an alcohol dehydrogenase present in the whole cell stereoselectively reduces the ketone of the acyloin and an erythro diol is formed instead. This is the first time that an acyloin-type enzymatic reaction with a ketone as substrate is reported. We propose the mechanism showed in Scheme 2.<smiles>CCC1CCC(=O)CC1</smiles><smiles>CCC(C)[C@@H](C)CC(=O)OC(C)=O</smiles><smiles>CCC1CCC(O)(C(C)=O)CC1</smiles>
$\underset{\text { dehydrogenase }}{\stackrel{\text { alcohol }}{\longrightarrow}}$<smiles>CC[C@H]1CC[C@](O)(C(C)O)CC1</smiles>

1c
Scheme 2. Mechanism of the acyloin-type reaction.

Another interesting transformation of $\mathbf{1}$ was oxidation at tertiary carbon C-4 by the endophytic fungus Xylaria sp. which is unusual for fungal biotransformations. 4-Ethyl-4-hydroxycyclohexanone 1d had been previously prepared ${ }^{13}$ but it is reported here for the first time as a biotransformation product.

The biotransformation of 4-ethylcyclohexanone 1 by the endophytic fungi Xylaria sp. and C. crassipes also produced another compound, 1e, whose ${ }^{13} \mathrm{C}$ NMR spectrum was consistent with the molecular formula $\mathrm{C}_{8} \mathrm{H}_{14} \mathrm{O}_{2}$, exhibiting signals for one methyl, four methylene, two methyne and one quaternary carbon. The ${ }^{1} \mathrm{H}$ NMR spectrum was close to that of 4-ethylcyclohexanone $\mathbf{1}$, but the presence of a signal at $70.7 \mathrm{ppm}$ in the ${ }^{13} \mathrm{C}$ NMR spectrum (C-7) and two signals at $3.73 \mathrm{ppm}(\mathrm{q}, 1 \mathrm{H})$ and $1.25 \mathrm{ppm}(\mathrm{d}, 3 \mathrm{H})$ in the ${ }^{1} \mathrm{H}$ NMR spectrum suggest that this compound was hydroxylated at C-7. The stereochemistry of this product was confirmed by means of the corresponding Mosher esters. ${ }^{11}$ According to this method, we analysed the ${ }^{1} \mathrm{H}$ NMR spectra of the MPA esters of compound 1e resulting from the biotransformation by Xylaria sp. on surface cultures at 10 days. The positive value of $\Delta \delta^{R S}$ for $\mathrm{H}-8$ $(+0.15)$ and the negative value of $\Delta \delta^{R S}$ for $\mathrm{H}-4$ and $\mathrm{H}-6(-0.59$ and -0.14 , respectively) indicate an $R$ configuration for this compound, with $[\alpha]_{\mathrm{D}}^{25}=-3.5\left(c 1.0, \mathrm{CHCl}_{3}\right)$. The same compound $1 \mathrm{e}$ obtained from $C$. crassipes showed a positive value for $[\alpha]_{\mathrm{D}}^{25}$, suggesting an $S$-configuration for C-7.

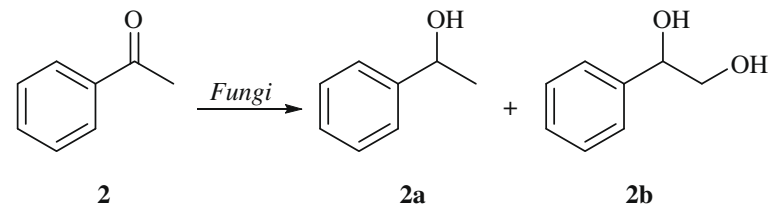

Scheme 3. Biotransformation of acetophenone 2 .

4-(1-Hydroxyethyl)cyclohexanone 1e had been previously prepared $^{14}$ but its absolute configuration is reported here for the first time.

These compounds 1d and 1e were only obtained by the endophytic fungi Xylaria sp. and C. crassipes, indicating the different biocatalytic potential of these fungi.

\subsection{Biotransformation of acetophenone 2}

Acetophenone $\mathbf{2}$ was biotransformed by whole cells of five filamentous fungi, B. cinerea, E. lata, T. viride, C. crassipes and Xylaria sp. to verify the biocatalytic potential of these fungi for the biotransformation of aromatic ketones (Scheme 3). The results of the biotransformations are presented in Tables 3 (static cultures) and 4 (shaken cultures) in terms of isolated yields, enantiomeric excesses and the predominant configurations of the products obtained. Shaken cultures were included in order to observe the differences due to the degree of oxidation in the compounds obtained.

In order to evaluate the alcohol dehydrogenase activity for each fungus under study, we selected the time for the biotransformation. The absolute configurations were attributed by comparison with those from the literature. ${ }^{15,16}$

The most enantioselective strain for the bioreduction reaction was $B$. cinerea, which gave $(S)-1$-phenylethanol $(S)-\mathbf{2} \mathbf{a}^{15}$ with high enantiomeric excess (85\%) and conversion (54.3\%) on surface cultures, and $92 \%$ ee and $23 \%$ yield on shaken cultures. The $(S)$-configuration is consistent with Prelog's rule. ${ }^{12} T$. viride showed enantiopreference for the $(R)$-alcohol $(R)$-2a with a high enantiomeric excess (79\%). Therefore, depending on the configuration of the chiral alcohol required, either $B$. cinerea or $T$. viride can be used.

The data presented in tables show that the enantiomeric excess decreased with the fermentation time, except for the shaken culture of $B$. cinerea. This is because in both cases the highest enantiomeric excess was reached after five days.

It is interesting to note that $C$. crassipes was the only fungus which gave the hydroxylation product of $\mathbf{2 a}$ at $\mathrm{C}-2$, phenylethane-1,2-diol $\mathbf{2 b},{ }^{16}$ with (S)-configuration and high enantiomeric excess.

Table 3

Biotransformation of acetophenone $\mathbf{2}$ on surface cultures

\begin{tabular}{|c|c|c|c|c|c|c|c|}
\hline \multirow[t]{2}{*}{ Microorg. } & \multirow[t]{2}{*}{ Time (days) } & \multicolumn{3}{|c|}{ Phenylethanol 2a } & \multicolumn{3}{|c|}{ Phenylethane-1,2-diol 2b } \\
\hline & & Yield (\%) & $\mathrm{ee}^{\mathrm{a}}(\%)$ & Config. $^{\mathrm{b}}$ & Yield (\%) & $\mathrm{ee}^{\mathrm{a}}(\%)$ & Config. ${ }^{c}$ \\
\hline \multirow[t]{2}{*}{ B. cinerea } & 5 & 54.3 & 85 & $(S)$ & - & - & - \\
\hline & 10 & 36.4 & 65 & $(S)$ & - & - & - \\
\hline \multirow[t]{2}{*}{ T. viride } & 5 & 47.0 & 70 & $(R)$ & - & - & - \\
\hline & 10 & 35.7 & 62 & $(R)$ & - & - & - \\
\hline \multirow[t]{2}{*}{ E. lata } & 8 & 4.7 & 19 & $(S)$ & - & - & - \\
\hline & 15 & 11.1 & 4 & $(S)$ & - & - & - \\
\hline \multirow[t]{2}{*}{ C. crassipes } & 5 & 2.2 & 8 & $(R)$ & - & - & - \\
\hline & 10 & - & - & - & 2.5 & 76 & $(S)$ \\
\hline \multirow[t]{2}{*}{ Xylaria sp. } & 5 & - & - & - & - & - & - \\
\hline & 10 & 4.2 & 10 & $(S)$ & - & - & - \\
\hline
\end{tabular}

\footnotetext{
a ee: enantiomeric excess was determined by means of HPLC analyses.

b Lit. $^{15}$

c Lit.; ${ }^{16}$ config.: absolute configuration.
} 
Table 4

Biotransformation of acetophenone $\mathbf{2}$ on shaken cultures

\begin{tabular}{|c|c|c|c|c|c|c|c|}
\hline \multirow[t]{2}{*}{ Microorg. } & \multirow[t]{2}{*}{ Time (days) } & \multicolumn{3}{|c|}{ Phenylethanol 2a } & \multicolumn{3}{|c|}{ Phenylethane-1,2-diol $\mathbf{2 b}$} \\
\hline & & Yield (\%) & $\mathrm{ee}^{\mathrm{a}}(\%)$ & Config. ${ }^{b}$ & Yield (\%) & $\mathrm{ee}^{\mathrm{a}}(\%)$ & Config. $^{c}$ \\
\hline \multirow[t]{2}{*}{ B. cinerea } & 2 & 36.0 & 65 & $(S)$ & - & - & - \\
\hline & 5 & 23.0 & 92 & $(S)$ & - & - & - \\
\hline \multirow[t]{2}{*}{ T. viride } & 5 & 58.2 & 79 & $(R)$ & - & - & - \\
\hline & 10 & 65.5 & 73 & $(R)$ & - & - & - \\
\hline \multirow[t]{2}{*}{ E. lata } & 8 & 29.1 & 22 & $(S)$ & - & - & - \\
\hline & 15 & 27.0 & 15 & $(S)$ & - & - & - \\
\hline \multirow[t]{2}{*}{ C. crassipes } & 5 & 14.5 & 31 & $(R)$ & - & - & - \\
\hline & 10 & - & - & - & 4.6 & 90 & $(S)$ \\
\hline \multirow[t]{2}{*}{ Xylaria sp. } & 5 & - & - & - & - & - & - \\
\hline & 10 & 0.9 & 62 & $(S)$ & - & - & - \\
\hline
\end{tabular}

a ee: enantiomeric excess was determined by means of HPLC analyses.

${ }^{\mathrm{b}}$ Lit. $^{15}$.

c Lit.; ${ }^{16}$ config.: absolute configuration.

\section{Conclusions}

In summary, the studies described above demonstrate the biocatalytic potential of the filamentous fungi $B$. cinerea, $T$. viride, $E$. lata, $C$. crassipes and Xylaria sp. in obtaining biotransformation compounds with high enantiomeric purity from prochiral ketones. The main reaction paths involved reduction and hydroxylations at several positions including tertiary carbons. The latter case is not very typical in fungal biotransformations. Thus, 4-ethyl-4-hydroxycyclohexanone 1d is obtained by the endophytic fungus Xylaria sp.

4-Ethylcyclohexanone 1 was reduced to the corresponding cis and trans-alcohols by all the fungi with medium to high enantiomeric purity, except by Xylaria sp. B. cinerea was very effective in the bioreduction of both substrates leading to the chiral alcohol (S)-1-phenylethanol $(S)$-2a with up to $90 \%$ enantiomeric excess and the ratio of cis- and trans-4-ethylcyclohexanol 1a was shown to be 0:100.

Moreover, the absolute configurations of the compounds trans4-ethyl-1-(1S-hydroxyethyl)cyclohexanol 1c and 4-(1R-hydroxyethyl)cyclohexanone 1e were determined by NMR analysis of the corresponding Mosher's esters. The first one, 1c, reported here for the first time, was obtained through biotransformation by $T$. viride and $E$. lata by means of an atypical acyloin-type reaction.

The high yields observed for Eutypa and its ability to carry out an unreported acyloin-type reaction seem to indicate that this fungus could be a potential biocatalyst.

\section{Experimental}

\subsection{General experimental procedures}

Optical rotations were determined using a Perkin-Elmer 241 polarimeter. IR spectra were recorded on a Mattson Genesis spectrophotometer, series FTIR. ${ }^{1} \mathrm{H}$ and ${ }^{13} \mathrm{C}$ NMR measurements were obtained on Varian Gemini 300 and Varian Unity 400 NMR spectrometers with $\mathrm{SiMe}_{4}$ as the internal reference. Mass spectra were recorded on a GC-MS Thermoquest spectrometer (model: Voyager) and a VG Autospec-Q spectrometer. HPLC was performed with a Hitachi/Merck L-6270 apparatus equipped with a UV-vis detector (L 6200) and a differential refractometer detector (RI-71). TLC was performed on Merck Kiesegel $60 \mathrm{~F}_{254}, 0.2 \mathrm{~mm}$ thick. Silica gel (Merck) was used for column chromatography. Purification by means of HPLC was accomplished with a silica gel column (Hibar $60,7 \mathrm{~m}, 1 \mathrm{~cm}$ wide, $25 \mathrm{~cm}$ long). Chemicals were products of Fluka or Aldrich. All solvents used were freshly distilled.

\subsection{Microorganism cultures}

The B. cinerea culture employed in this work, B. cinerea (UCA 992), was obtained from grapes from the Domecq vineyard, Jerez de la Frontera, Cádiz, Spain. This culture of B. cinerea is deposited in the Universidad de Cadiz, Facultad de Ciencias, Mycological Herbarium Collection (UCA). The E. lata and T. viride cultures used were obtained from the 'Colección Española de Cultivos Tipo' (CECT), Facultad de Biología, Universidad de Valencia, Spain, where cultures of these strains are deposited. C. crassipes and Xylaria sp. were isolated as endophytes from the plant Casearia sylvestris (Flacourtiaceae) from Cerrado do Estado de São Paulo (Brazil). ${ }^{17}$ These strains are deposited in the Herbário do Instituto de Botânica de São Paulo (Brazil).

\subsection{Determination of enantiomeric purity}

The enantiomeric and diastereoisomeric excesses of $\mathbf{1 b}$ were determined by chiral GC analyses on a Cyclosil-B, $30 \mathrm{~m} \times 0.25$ $\mathrm{mm} \times 0.25 \mu \mathrm{m}$ column using a Perkin-Elmer, Clarus 400 gas chromatograph; split at $50 \mathrm{~mL} / \mathrm{min}$, flow rate $1.1 \mathrm{~mL} / \mathrm{min}$, hydrogen as a gas carrier; trans-(major)-1b $t_{\mathrm{R}}=4.76 \mathrm{~min}$, trans $-($ minor $)-\mathbf{1 b} t_{\mathrm{R}}=$ $5.87 \mathrm{~min}$; cis-(minor)-1b $t_{\mathrm{R}}=4.54 \mathrm{~min}$, cis-(major) $-\mathbf{1 b} t_{\mathrm{R}}=4.75 \mathrm{~min}$.

The enantiomeric purity of $\mathbf{2 a}$ and $\mathbf{2 b}$ was determined by means of HPLC analyses on a chiral column (Chiralcel OD, Daicel, Japan): $254 \mathrm{~nm}, 0.8 \mathrm{~mL} / \mathrm{min}$, hexane/isopropanol (9:1); $(R)-2 \mathrm{a} t_{\mathrm{R}}=7.4 \mathrm{~min}$, $(S)-2 \mathbf{a} t_{\mathrm{R}}=8.6 \mathrm{~min},(R)-\mathbf{2 b} t_{\mathrm{R}}=20.6 \mathrm{~min},(S)-\mathbf{2 b} t_{\mathrm{R}}=22.0 \mathrm{~min}$. The absolute configurations were attributed by comparison with those from the literature. ${ }^{15,16}$

\subsection{General procedure for biotransformation}

Fungi were grown at $25^{\circ} \mathrm{C}$ on a Czapeck-Dox medium (B. cinerea UCA 992) or on a PDB medium (T. viride, E. lata, C. crassipes and Xylaria sp.) (150 mL per bottle and $200 \mathrm{~mL}$ per flask). The shaken cultures were incubated in an orbital shaker at $140 \mathrm{rpm}$. The substrates were dissolved in ethanol and then distributed over Roux bottles or flasks (150 ppm per flask) and the fermentation continued for a further period, after which the mycelium was filtered and then washed with brine and ethyl acetate. The broth was extracted three times with ethyl acetate and the extract was dried over anhydrous sodium sulfate. The solvent was then evaporated and the residue was chromatographed first on a silica gel column and then with HPLC with an increasing gradient of ethyl acetate to petroleum ether.

\subsection{Biotransformation of 4-ethylcyclohexanone 1}

\subsubsection{Biotransformation by $B$. cinerea}

(a) Static culture: 4-Ethylcyclohexanone $\mathbf{1}$ was dissolved in ethanol and then distributed over 12 Roux bottles after two days' growth. The fermentation was allowed to continue for five more days in six of the bottles and 10 more days in the other six bottles. Chromatography of the extract fermented for five days gave 4-eth- 
ylcyclohexanone 1 (1.5 mg) and trans-4-ethylcyclohexanol trans1a $(28.6 \mathrm{mg})$. Chromatography of the extract fermented for 10 days gave trans-4-ethylcyclohexanol trans-1a $(11.2 \mathrm{mg})$ and trans-4-(1hydroxyethyl)cyclohexanol trans-1b (5.0 mg). (b) Shaken culture: 4-Ethylcyclohexanone (1) was dissolved in ethanol and then distributed in 10 flasks $(500 \mathrm{~mL})$ in an orbital shaker after two days' growth. The fermentation was allowed to continue for five more days in five of the flasks and 10 more days in the other five flasks. Chromatography of the extract fermented for five days gave trans4-ethylcyclohexanol trans-1a $(38.0 \mathrm{mg})$ and trans-4-(1-hydroxyethyl)cyclohexanol trans-1b $(2.0 \mathrm{mg})$. Chromatography of the extract fermented for 10 days gave trans-4-ethylcyclohexanol trans-1a (9.7 mg) and trans-4-(1-hydroxyethyl)cyclohexanol trans-1b $(1.7 \mathrm{mg})$.

\subsubsection{Biotransformation by $T$. viride}

(a) Static culture: 4-Ethylcyclohexanone $\mathbf{1}$ was dissolved in ethanol and then distributed in 18 Roux bottles after two days' growth. The fermentation was allowed to continue for two more days in six of the bottles and for five more days in the other twelve bottles. Chromatography of the extract fermented for two days gave 6-pentyl- $\alpha$-pyrone ${ }^{18}$ (15.9 mg), cis-4-ethylcyclohexanol cis1a $(22.1 \mathrm{mg})$, trans-4-ethylcyclohexanol trans-1a $(3.6 \mathrm{mg})$ and trans-4-ethyl-1-(1S-hydroxyethyl)cyclohexanol 1c $\left([\alpha]_{\mathrm{D}}^{25}=-1.6(c\right.$ $\left.\left.0.05, \mathrm{CHCl}_{3}\right)\right)(1.7 \mathrm{mg})$. Chromatography of the extract fermented for five days gave 6 -pentyl- $\alpha$-pyrone $(100.0 \mathrm{mg})$, cis-4-ethylcyclohexanol cis-1a $(100.0 \mathrm{mg})$, trans-4-ethylcyclohexanol trans-1a $(41.9 \mathrm{mg})$ and trichoviridine ${ }^{19}(30.0 \mathrm{mg})$. (b) Shaken culture: 4-Ethylcyclohexanone 1 was dissolved in ethanol and then distributed in 10 flasks $(500 \mathrm{~mL})$ in an orbital shaker on a PDB medium after two days' growth. The fermentation was allowed to continue for two more days in five of the flasks and for five more days in the other five flasks. Chromatography of the extract fermented for two days gave 6-pentyl- $\alpha$-pyrone $(82.0 \mathrm{mg})$, trichoviridine $(30.8 \mathrm{mg})$, cis-4ethylcyclohexanol cis-1a (10.0 mg) and trans-4-ethylcyclohexanol trans-1a $(5.8 \mathrm{mg})$. Chromatography of the extract fermented for five days gave 6-pentyl- $\alpha$-pyrone $(78 \mathrm{mg})$, trichoviridine (30.0 mg), cis-4-ethylcyclohexanol cis-1a $(26.0 \mathrm{mg})$ and trans-4ethylcyclohexanol trans-1a (15.8 mg).

\subsubsection{Biotransformation by $E$. lata}

(a) Static culture: 4-Ethylcyclohexanone $\mathbf{1}$ was dissolved in ethanol and then distributed in 24 Roux bottles after seven days' growth. The fermentation was allowed to continue on surface culture for eight more days in six of the bottles, for 15 more days in other six bottles and for 20 more days in the rest of the bottles. Chromatography of the extract fermented for eight days gave 4ethylcyclohexanone $\mathbf{1}$ (16.1 mg), cis-4-ethylcyclohexanol cis-1a (13.0 mg), trans-4-ethylcyclohexanol trans-1a (19.0 mg), 2-phenylethanol ${ }^{20}(3 \mathrm{mg})$ tyrosol $^{21}(1.0 \mathrm{mg})$, trans-4-ethyl-1-(1S-hydroxyethyl)cyclohexanol 1c $\left([\alpha]_{\mathrm{D}}^{25}=-0.1 \quad\left(\mathrm{c} \quad 0.1, \mathrm{CHCl}_{3}\right)\right) \quad(13.0 \mathrm{mg})$ and $p$-hydroxybenzoic acid ${ }^{22}(1.0 \mathrm{mg})$. Chromatography of the extract fermented for 15 days gave cis-4-ethylcyclohexanol cis-1a (20.8 mg), trans-4-ethylcyclohexanol trans-1a (40.9 mg), trans4-ethyl-1-(1S-hydroxyethyl)cyclohexanol 1c $\left([\alpha]_{\mathrm{D}}^{25}=-0.4\right.$ (c 0.1 , $\left.\mathrm{CHCl}_{3}\right)$ ) (10.2 mg), tyrosol $(12.2 \mathrm{mg}), p$-hydroxybenzoic acid $(20.8 \mathrm{mg})$ and $(R)-(-)-0$-methylmellein ${ }^{23}(6.2 \mathrm{mg})$. Chromatography of the extract fermented for 20 days gave cis-4-ethylcyclohexanol cis-1a $(10.3 \mathrm{mg})$, trans-4-ethylcyclohexanol trans-1a (52.0 mg), 2-phenylethanol (16.0 mg), trans-4-ethyl-1-(1S-hydroxyethyl)cyclohexanol 1c $\left([\alpha]_{\mathrm{D}}^{25}=-6.1\left(\mathrm{c} 0.1, \mathrm{CHCl}_{3}\right)\right)(23.0 \mathrm{mg})$ and tyrosol $(7.0 \mathrm{mg})$. (b) Shaken culture: 4-Ethylcyclohexanone 1 was dissolved in ethanol and then distributed in 10 flasks $(500 \mathrm{~mL})$ in an orbital shaker on a PDB medium after two days' growth. The fermentation was allowed to continue for eight more days in five of the flasks and for 15 more days in the other five flasks. Chromatog- raphy of the extract fermented for eight days gave cis-4-ethylcyclohexanol (cis-1a) (2.0 mg), trans-4-ethylcyclohexanol (trans-1a) (61.7 mg), trans-4-ethyl-1-(1S-hydroxyethyl)cyclohexanol (1c) $\left([\alpha]_{\mathrm{D}}^{25}=-2.5\left(\mathrm{c} 0.1, \mathrm{CHCl}_{3}\right)\right)(8.2 \mathrm{mg})$ and $(R)-(-)-O$-methylmellein $(11.0 \mathrm{mg})$. Chromatography of the extract fermented for 15 days gave cis-4-ethylcyclohexanol cis-1a (17.4 mg), trans-4-ethylcyclohexanol trans-1a (33.6 mg), trans-4-ethyl-1-(1S-hydroxyethyl)cyclohexanol (1c) $\left([\alpha]_{\mathrm{D}}^{25}=-4.0\left(\mathrm{c} \quad 0.1, \mathrm{CHCl}_{3}\right)\right)(11.0 \mathrm{mg})$ and $(R)-(-)-O$-methylmellein (10.4 mg).

\subsubsection{Biotransformation by $C$. crassipes}

(a) Static culture: 4-Ethylcyclohexanone $\mathbf{1}$ was dissolved in ethanol and then distributed in 12 Roux bottles after two days' growth. The fermentation was allowed to continue on surface culture for five more days in six of the bottles and for 10 more days in the other six bottles. Chromatography of the extract fermented for five days gave trans-4-ethylcyclohexanol trans-1a $(3.0 \mathrm{mg})$ and cis4-(1-hydroxyethyl)cyclohexanol cis-1b $(7.0 \mathrm{mg})$. Chromatography of the extract fermented for 10 days gave trans-4-ethylcyclohexanol trans-1a $(0.4 \mathrm{mg})$, cis-4-(1-hydroxyethyl)cyclohexanol cis-1b $(14.0 \mathrm{mg})$ and $4-\left(1 S\right.$-hydroxyethyl)cyclohexanone $(S)-\mathbf{1 e}\left([\alpha]_{\mathrm{D}}^{25}=\right.$ $\left.+4.1\left(\mathrm{c} 0.8, \mathrm{CHCl}_{3}\right)\right)(13.0 \mathrm{mg})$. (b) Shaken culture: 4-Ethylcyclohexanone 1 was dissolved in ethanol and then distributed in 10 flasks $(500 \mathrm{~mL})$ in an orbital shaker on a PDB medium after two days' growth. The fermentation was allowed to continue for five more days in five of the flasks and for 10 more days in the other five flasks. Chromatography of the extract fermented for five days gave trans-4-ethylcyclohexanol trans-1a $(5.0 \mathrm{mg})$ and 4 -(1Shydroxyethyl)cyclohexanone $(S)-\mathbf{1 e}\left([\alpha]_{\mathrm{D}}^{25}=+2.3\left(\right.\right.$ c $\left.\left.0.1, \mathrm{CHCl}_{3}\right)\right)$ $(10.0 \mathrm{mg})$. Chromatography of the extract fermented for 10 days gave trans-4-ethylcyclohexanol trans-1a $(0.5 \mathrm{mg})$ and $4-(1 S-$ hydroxyethyl)cyclohexanone $(S)-\mathbf{1 e}\left([\alpha]_{\mathrm{D}}^{25}=+2.9\left(\right.\right.$ c $\left.\left.0.1, \mathrm{CHCl}_{3}\right)\right)$ (2.0 mg).

\subsubsection{Biotransformation by Xylaria sp.}

(a) Static culture: 4-Ethylcyclohexanone $\mathbf{1}$ was dissolved in ethanol and then distributed in 12 Roux bottles after two days' growth. The fermentation was allowed to continue on surface culture for 5 more days in six of the bottles and for 10 more days in the other six bottles. Chromatography of the extract fermented for five days gave 4-ethyl-4-hydroxycyclohexanone $1 \mathrm{~d}(4.5 \mathrm{mg})$ and 4-(1R-hydroxyethyl)cyclohexanone $(R)-\mathbf{1 e}\left([\alpha]_{\mathrm{D}}^{25}=-3.5\left(\right.\right.$ c $\left.\left.0.5, \mathrm{CHCl}_{3}\right)\right)(3.0 \mathrm{mg})$. Chromatography of the extract fermented for 10 days gave 4 ethyl-4-hydroxycyclohexanone 1d $(5.0 \mathrm{mg})$ and 4-(1R-hydroxyethyl)cyclohexanone $(R)-\mathbf{1 e}\left([\alpha]_{\mathrm{D}}^{25}=-3.8\left(\right.\right.$ c $\left.\left.0.1, \mathrm{CHCl}_{3}\right)\right)(4.5 \mathrm{mg})$. (b) Shaken culture: 4-Ethylcyclohexanone 1 was dissolved in ethanol and then distributed in 10 flasks $(500 \mathrm{~mL})$ in an orbital shaker on a PDB medium after two days' growth. The fermentation was allowed to continue for five more days in five of the flasks and for 10 more days in the other five flasks. Chromatography of the extract fermented for five days gave 4-ethyl-4-hydroxycyclohexanone 1d $(3.5 \mathrm{mg})$ and 4 -(1R-hydroxyethyl)cyclohexanone $(R)-\mathbf{1 e}\left([\alpha]_{\mathrm{D}}^{25}=\right.$ $\left.-3.2\left(c 1.7, \mathrm{CHCl}_{3}\right)\right)(15.0 \mathrm{mg})$. Chromatography of the extract fermented for 10 days gave 4-ethyl-4-hydroxycyclohexanone 1d $(5.0 \mathrm{mg})$ and 4 - $\left(1 R\right.$-hydroxyethyl)cyclohexanone $(R)-\mathbf{1 e}\left([\alpha]_{\mathrm{D}}^{25}=\right.$ $-3.5\left(\right.$ ( $\left.\left.1.0, \mathrm{CHCl}_{3}\right)\right)(10.0 \mathrm{mg})$.

\subsection{6. trans-4-Ethylcyclohexanol trans $-1 a^{8}$}

Obtained as a colourless oil. ${ }^{1} \mathrm{H}$ NMR $\left(400 \mathrm{MHz}, \mathrm{CDCl}_{3}\right) \delta(\mathrm{ppm})$ : $0.86(3 \mathrm{H}, \mathrm{t}), 1.20(2 \mathrm{H}, \mathrm{m}), 2.85(4 \mathrm{H}, \mathrm{dd}), 3.55(1 \mathrm{H}, \mathrm{m}) .{ }^{13} \mathrm{C} \mathrm{NMR}$ $\left(100 \mathrm{MHz}, \mathrm{CDCl}_{3}\right) \delta(\mathrm{ppm}): 11.9,29.5,31.1,35.8,38.6,71.4$.

\subsection{7. cis-4-Ethylcyclohexanol cis-1 $\mathrm{a}^{8}$}

Obtained as a colourless oil. ${ }^{1} \mathrm{H}$ NMR $\left(400 \mathrm{MHz}, \mathrm{CDCl}_{3}\right) \delta(\mathrm{ppm})$ : $0.85(3 \mathrm{H}, \mathrm{t}), 0.99(2 \mathrm{H}, \mathrm{m}), 1.25(2 \mathrm{H}, \mathrm{m}), 1.30(2 \mathrm{H}, \mathrm{m}), 1.50(2 \mathrm{H}, \mathrm{m})$ 
$1.70(4 \mathrm{H}, \mathrm{dd}), 3.90(1 \mathrm{H}, \mathrm{m}) .{ }^{13} \mathrm{C} \mathrm{NMR}\left(100 \mathrm{MHz}, \mathrm{CDCl}_{3}\right) \delta(\mathrm{ppm})$ : $11.7,26.8,32.5,38.2,67.4$.

\subsubsection{4-(1-Hydroxyethyl)cyclohexanol $1 \mathrm{bb}^{9}$}

Obtained as a colourless oil. ${ }^{1} \mathrm{H}$ NMR $\left(400 \mathrm{Mhz}, \mathrm{CDCl}_{3}\right) \delta(\mathrm{ppm})$ : $1.16(3 \mathrm{H}, \mathrm{d}, J=6.4 \mathrm{~Hz}, \mathrm{H}-8), 1.71(2 \mathrm{H}, \mathrm{m}, \mathrm{H}-3), 1.76(2 \mathrm{H}, \mathrm{m}, \mathrm{H}-5)$, $1.97(4 \mathrm{H}, \mathrm{m}, \mathrm{H}-2, \mathrm{H}-6), 3.55(1 \mathrm{H}, \mathrm{m}, \mathrm{H}-7), 3.67(1 \mathrm{H}, \mathrm{t}, J=6.7 \mathrm{~Hz}$, $\mathrm{H}-1) .{ }^{13} \mathrm{C}$ NMR $\left(100 \mathrm{MHz}, \mathrm{CDCl}_{3}\right) \delta(\mathrm{ppm}): 20.8$ (c, C-8), 26.3 (t, C3), 26.8 (t, C-5), 35.2 (t, C-2), 35.3 (t, C-6), 44.0 (d, C-4), 70.9 (d, C-1), $71.6(d, C-7)$.

\subsection{9. trans-4-Ethyl-1-(1S-hydroxyethyl)cyclohexanol 1c}

Obtained as a colourless oil. IR $v_{\max }\left(\mathrm{cm}^{-1}\right): 3401,2927,2855$, 1704, 1455, 1377, 960. ${ }^{1} \mathrm{H}$ NMR $\left(400 \mathrm{MHz}, \mathrm{CDCl}_{3}\right) \delta$ (ppm): 0.88 $(3 \mathrm{H}, \mathrm{t}, J=7.3 \mathrm{~Hz}, \mathrm{H}-8), 1.07(1 \mathrm{H}, \mathrm{m}, \mathrm{H}-4), 1.15(3 \mathrm{H}, \mathrm{d}, J=6.4 \mathrm{~Hz}$, $\mathrm{H}-10), 1.24$ (5H, m, H-7, H-3, H-5, H-6), $1.31(1 \mathrm{H}, \mathrm{td}, J=13.4 \mathrm{~Hz}$, $J=3.8 \mathrm{~Hz}, \mathrm{H}-2), 1.62$ (3H, m, H-3', H-5', H-6'), 1.68 (1H, m, H-2'), $3.52(1 \mathrm{H}, \mathrm{c}, J=6.4 \mathrm{~Hz}, \mathrm{H}-9) .{ }^{13} \mathrm{C}$ NMR $\left(100 \mathrm{MHz}, \mathrm{CDCl}_{3}\right) \delta(\mathrm{ppm})$ : 11.5 (c, C-8), 17.1 (c, C-10), 27.5 (t, C-5), 27.6 (t, C-3), 29.6 (t, C7), 30.7 (t, C-6), 34.0 (t, C-2), 39.1 (d, C-4), $73.4(\mathrm{~s}, \mathrm{C}-1), 74.6$ (d, C-9). MS $m / z 172.2\left(\mathrm{M}^{+}\right), 154.1\left[\mathrm{M}-\mathrm{H}_{2} \mathrm{O}\right]^{+}, 127$ (100), 109 (48), 67 (51). HRMS: calcd for $\mathrm{C}_{10} \mathrm{H}_{20} \mathrm{O}_{2}$ : 172.1463; found 154.1339 $\left[\mathrm{M}-\mathrm{H}_{2} \mathrm{O}\right]^{+}$.

\subsubsection{4-(1-Hydroxyethyl)cyclohexanone $1 \mathrm{e}^{14}$}

Obtained as a colourless oil. ${ }^{1} \mathrm{H}$ NMR $\left(400 \mathrm{MHz}, \mathrm{CDCl}_{3}\right) \delta(\mathrm{ppm})$ : 1.25 (3H, d, J = $6 \mathrm{~Hz}, \mathrm{H}-8), 1.75$ (1H, m, H-4), 2.03 (2H, m, H-3), 2.35 (2H, m, H-2), 2.40 (2H, m, H-6), $3.73(1 \mathrm{H}, \mathrm{q}, J=6 \mathrm{~Hz}, \mathrm{H}-7) .{ }^{13} \mathrm{C}$ NMR $\left(100 \mathrm{MHz}, \mathrm{CDCl}_{3}\right) \delta(\mathrm{ppm}): 21.0$ (c, C-8), 27.9 (t, C-5), 28.4 (t, C-3), 40.4 (t, C-2), 40.5 (t, C-6), 43.2 (d, C-4), 70.7 (d, C-7), 211.0 (s, C-1).

\subsection{Mosher's esters: general procedure}

DMAP (3.96 mg, 2.0 equiv), DCC (7.0 mg, 2.1 equiv) and $(R)-$ MPA or (S)-MPA ( $6 \mathrm{mg}, 2.25$ equiv) were added to a stirred solution of the corresponding compound, $1 \mathbf{c}$ or $1 \mathbf{e}(2.3 \mathrm{mg}, 0.016 \mathrm{mmol})$ in dry dichloromethane $(1 \mathrm{~mL})$ at room temperature. The resulting mixture was stirred for 1-2 h. and was then concentrated under reduced pressure. The residue was chromatographed using a silica gel column followed by HPLC purification to afford the desired compounds $(R)$-MPA-1c, $(S)$-MPA-1c and $(R)-M P A-1 e,(S)-M P A-1 e$ with an average yield of $62 \%$.

\subsection{1. (R)-MPA ester of trans-4-ethyl-1-(1S-hydroxyethyl)cyclo- hexanol $(R)-M P A-1 C$}

${ }^{1} \mathrm{H} \mathrm{NMR}\left(400 \mathrm{MHz}, \mathrm{CDCl}_{3}\right) \delta(\mathrm{ppm}): 0.86(3 \mathrm{H}, \mathrm{t}, J=7.6 \mathrm{~Hz}, \mathrm{H}-8)$, $1.05(3 \mathrm{H}, \mathrm{d}, J=6.4 \mathrm{~Hz}, \mathrm{H}-10), 1.21(4 \mathrm{H}, \mathrm{m}, \mathrm{H}-3, \mathrm{H}-5), 1.22(2 \mathrm{H}, \mathrm{m}, \mathrm{H}-$ 7), $1.52(1 \mathrm{H}, \mathrm{m}, \mathrm{H}-4), 1.54(4 \mathrm{H}, \mathrm{m}, \mathrm{H}-2, \mathrm{H}-6), 3.39$ (3H, s, OMe), 4.77 $(1 \mathrm{H}, \mathrm{c}, J=6.4 \mathrm{~Hz}, \mathrm{H}-9), 4.78(1 \mathrm{H}, \mathrm{s}, \mathrm{MPA}-\mathrm{H}), 7.30-7.42(\mathrm{~m}, 10 \mathrm{H}$, ArH).

\subsection{2. (S)-MPA ester of trans-4-ethyl-1-(1S-hydroxyethyl)cyclo- hexanol $(S)$-MPA-1c}

${ }^{1} \mathrm{H} \mathrm{NMR}\left(400 \mathrm{MHz}, \mathrm{CDCl}_{3}\right) \delta(\mathrm{ppm}): 0.82(3 \mathrm{H}, \mathrm{t}, J=7.2 \mathrm{~Hz}, \mathrm{H}-8)$, $1.06(1 \mathrm{H}, \mathrm{m}, \mathrm{H}-4), 1.16(4 \mathrm{H}, \mathrm{m}, \mathrm{H}-3, \mathrm{H}-5), 1.19(3 \mathrm{H}, \mathrm{d}, J=6.4 \mathrm{~Hz}, \mathrm{H}-$ 10), 1.21 ( $2 \mathrm{H}, \mathrm{m}, \mathrm{H}-7), 1.44$ (4H, m, H-2, H-6), 3.39 (3H, s, OMe), $4.72(1 \mathrm{H}, \mathrm{c}, J=6.4 \mathrm{~Hz}, \mathrm{H}-9), 4.75(1 \mathrm{H}, \mathrm{s}, \mathrm{MPA}-\mathrm{H}), 7.30-7.42(\mathrm{~m}$, $10 \mathrm{H}, \mathrm{ArH})$.

\subsection{3. (R)-MPA ester of 4-(1R-hydroxyethyl)cyclohexanone $(R)$ - MPA-1e}

${ }^{1} \mathrm{H}$ NMR (400 MHz, $\left.\mathrm{CDCl}_{3}\right) \delta(\mathrm{ppm}): 1.24(3 \mathrm{H}, \mathrm{d}, J=6 \mathrm{~Hz}, \mathrm{H}-8)$, $1.71(1 \mathrm{H}, \mathrm{m}, \mathrm{H}-4), 2.07$ (2H, m, H-3), $2.14(2 \mathrm{H}, \mathrm{m}, \mathrm{H}-2), 2.23(2 \mathrm{H}$, m, H-6), $3.40(3 \mathrm{H}, \mathrm{s}, \mathrm{OMe}), 4.74(1 \mathrm{H}, \mathrm{s}, \mathrm{MPA}-\mathrm{H}), 4.90(1 \mathrm{H}, \mathrm{q}$, $J=6 \mathrm{~Hz}, \mathrm{H}-7), 7.30-7.42(\mathrm{~m}, 10 \mathrm{H}, \mathrm{ArH})$.
4.6.4. (S)-MPA ester of 4-(1R-hydroxyethyl)cyclohexanone $(S)$ MPA-1e

${ }^{1} \mathrm{H}$ NMR (400 MHz, $\left.\mathrm{CDCl}_{3}\right) \delta(\mathrm{ppm}): 1.09(3 \mathrm{H}, \mathrm{d}, J=6 \mathrm{~Hz}, \mathrm{H}-8)$, $2.30(1 \mathrm{H}, \mathrm{m}, \mathrm{H}-4), 2.37$ (2H, m, H-6), $3.40(3 \mathrm{H}, \mathrm{s}, \mathrm{OMe}), 4.75(1 \mathrm{H}$, s, MPA-H), 4.92 (1H, q, J = 6 Hz, H-7), 7.30-7.42 (m, 10H, ArH).

\subsection{Biotransformation of acetophenone 2}

\subsubsection{Biotransformation by $B$. cinerea}

(a) Static culture: Acetophenone $\mathbf{2}$ was dissolved in ethanol and then distributed in 12 Roux bottles after two days' growth. The fermentation was allowed to continue for five more days in six of the bottles and 10 more days in the other six bottles. Chromatography of the extract fermented for five days gave acetophenone 2 $(4.2 \mathrm{mg})$, dihydrobotrydial ${ }^{24}(2.0 \mathrm{mg})$ and $(S)$-1-phenylethanol $(S)-2 \mathbf{a}\left([\alpha]_{\mathrm{D}}^{25}=-47.0\left(\right.\right.$ c $\left.\left.1.2, \mathrm{CHCl}_{3}\right)\right)(72.3 \mathrm{mg})$. Chromatography of the extract fermented for 10 days gave dihydrobotrydial $(4.3 \mathrm{mg})$ and (S)-1-phenylethanol (S)-2a $\left([\alpha]_{\mathrm{D}}^{25}=-35.0\right.$ (c 1.5, $\left.\mathrm{CHCl}_{3}\right)$ ) $(50.0 \mathrm{mg})$. (b) Shaken culture: Acetophenone 2 was dissolved in ethanol and then distributed in 10 flasks $(500 \mathrm{~mL})$ in an orbital shaker after two days' growth. The fermentation was allowed to continue for two more days in five of the flasks and five more days in the other five flasks. Chromatography of the extract fermented for two days gave acetophenone $\mathbf{2}(12.0 \mathrm{mg})$ and $(S)$-1-phenylethanol $(S)-2 a\left([\alpha]_{\mathrm{D}}^{25}=-33.0\right.$ (c 2.1, $\left.\left.\mathrm{CHCl}_{3}\right)\right)(45.0 \mathrm{mg})$. Chromatography of the extract fermented for five days gave acetophenone (2) $(6.3 \mathrm{mg})$ and $(S)-1$-phenylethanol $(S)-\mathbf{2 a}\left([\alpha]_{\mathrm{D}}^{25}=-50.0\right.$ (c 1.4 , $\left.\mathrm{CHCl}_{3}\right)$ ) (30.0 mg).

\subsubsection{Biotransformation by $T$. viride}

(a) Static culture: Acetophenone $\mathbf{2}$ was dissolved in ethanol and then distributed in 18 Roux bottles after two days' growth. The fermentation was allowed to continue for five more days in twelve of the bottles and for 10 more days in the other six bottles. Chromatography of the extract fermented for five days gave acetophenone 2 (9.3 mg), 6-pentyl- $\alpha$-pyrone $(100.0 \mathrm{mg})$, trichoviridine (3.6 mg), (R)-1-phenylethanol $(R)-\mathbf{2 a}\left([\alpha]_{\mathrm{D}}^{25}=+36.0\left(\right.\right.$ c $\left.\left.1.0, \mathrm{CHCl}_{3}\right)\right)$ $(60.0 \mathrm{mg})$ and tyrosol $(3.6 \mathrm{mg})$. Chromatography of the extract fermented for 10 days gave 6-pentyl- $\alpha$-pyrone $(62.0 \mathrm{mg})$ and $(R)$ 1-phenylethanol $(R)-2 \mathrm{a}\left([\alpha]_{\mathrm{D}}^{25}=+34.0\left(\mathrm{c} 0.8, \mathrm{CHCl}_{3}\right)\right)(49.0 \mathrm{mg})$. (b) Shaken culture: Acetophenone $\mathbf{2}$ was dissolved in ethanol and then distributed in 10 flasks $(500 \mathrm{~mL})$ in an orbital shaker on a PDB medium after two days' growth. The fermentation was allowed to continue for 5 more days in five of the flasks and for 10 more days in the other five flasks. Chromatography of the extract fermented for five days gave acetophenone $\mathbf{2}(13.5 \mathrm{mg}), 6$-pentyl$\alpha$-pyrone $(60.0 \mathrm{mg})$, trichoviridine $(20.7 \mathrm{mg})$ and $(R)-1$-phenylethanol $(R)-2 a\left([\alpha]_{\mathrm{D}}^{25}=+39.0\left(c\right.\right.$ 1.7, $\left.\left.\mathrm{CHCl}_{3}\right)\right)(72.0 \mathrm{mg})$. Chromatography of the extract fermented for 10 days gave 6 -pentyl- $\alpha$-pyrone $(118.0 \mathrm{mg})$ and $(R)-1$-phenylethanol $(R)-\mathbf{2 a}\left([\alpha]_{\mathrm{D}}^{25}=+36.0(c \quad 0.8\right.$, $\left.\left.\mathrm{CHCl}_{3}\right)\right)(90.0 \mathrm{mg})$.

\subsubsection{Biotransformation by $E$. lata}

(a) Static culture: Acetophenone $\mathbf{2}$ was dissolved in ethanol and then distributed in 12 Roux bottles after seven days' growth. The fermentation was allowed to continue on surface culture for eight more days in six of the bottles and for 15 more days in the other six bottles. Chromatography of the extract fermented for eight days gave acetophenone $\mathbf{2}(38.0 \mathrm{mg}),(S)$-1-phenylethanol (S)-2a $\left([\alpha]_{\mathrm{D}}^{25}=-9.0\left(\right.\right.$ c $\left.\left.0.1, \mathrm{CHCl}_{3}\right)\right)(4.7 \mathrm{mg}), 2$-phenylethanol $(6.8 \mathrm{mg})$ and tyrosol $(2.1 \mathrm{mg})$. Chromatography of the extract fermented for 15 days gave acetophenone $\mathbf{2}(38.0 \mathrm{mg})$ and $(S)$-1-phenyletha$\operatorname{nol}(S)-\mathbf{2 a}\left([\alpha]_{\mathrm{D}}^{25}=-2.0\left(\right.\right.$ c $\left.\left.0.1, \mathrm{CHCl}_{3}\right)\right)(11.0 \mathrm{mg})$. (b) Shaken culture: Acetophenone $\mathbf{2}$ was dissolved in ethanol and then distributed in 10 flasks $(500 \mathrm{~mL})$ in an orbital shaker on a PDB medium after two days' growth. The fermentation was allowed to continue for 
eight more days in five of the flasks and for 15 more days in the other five flasks. Chromatography of the extract fermented for eight days gave $(S)-1$-phenylethanol $(S)$-2a $\left([\alpha]_{\mathrm{D}}^{25}=-12.0\right.$ (c 0.2 , $\left.\mathrm{CHCl}_{3}\right)$ ) $(40.0 \mathrm{mg}), 2$-phenylethanol $(5.0 \mathrm{mg})$ and $(\mathrm{R})-(-)-O$-methylmellein $(11.1 \mathrm{mg})$. Chromatography of the extract fermented for 15 days gave $(S)-1$-phenylethanol $(S)-2 a\left([\alpha]_{\mathrm{D}}^{25}=-8.0\right.$ (c 0.1 , $\left.\mathrm{CHCl}_{3}\right)$ ) $(37.0 \mathrm{mg}$ ) and $(R)-(-)-0$-methylmellein $(8.7 \mathrm{mg})$.

\subsubsection{Biotransformation by $C$. crassipes}

(a) Static culture: Acetophenone $\mathbf{2}$ was dissolved in ethanol and then distributed in 12 Roux bottles after two days' growth. The fermentation was allowed to continue on surface culture for five more days in six of the bottles and for 10 more days in the other six bottles. Chromatography of the extract fermented for five days gave $(R)-1$-phenylethanol $(R)-2 \mathbf{a}\left([\alpha]_{\mathrm{D}}^{25}=+4.3\left(c 0.5, \mathrm{CHCl}_{3}\right)\right)$ $(3.0 \mathrm{mg})$. Chromatography of the extract fermented for 10 days gave (S)-1-phenylethane-1,2-diol $(S)$-2b $\quad\left([\alpha]_{\mathrm{D}}^{25}=+26.0 \quad\right.$ (c) 0.7 , $\left.\mathrm{CHCl}_{3}\right)$ ) $(2.3 \mathrm{mg}$ ). (b) Shaken culture: Acetophenone 2 was dissolved in ethanol and then distributed in 10 flasks $(500 \mathrm{~mL})$ in an orbital shaker on a PDB medium after two days' growth. The fermentation was allowed to continue for five more days in five of the flasks and for 10 more days in the other five flasks. Chromatography of the extract fermented for five days gave $(R)$-1-phenylethanol $(R)-2 \mathbf{a}$ $\left([\alpha]_{\mathrm{D}}^{25}=+16.8\left(c 1.7, \mathrm{CHCl}_{3}\right)\right)(20.0 \mathrm{mg})$. Chromatography of the extract fermented for 10 days gave $(S)$-1-phenylethane-1,2-diol $(S)$ 2b $\left([\alpha]_{\mathrm{D}}^{25}=+30.6\left(c 0.1, \mathrm{CHCl}_{3}\right)\right)(7.2 \mathrm{mg})$.

\subsubsection{Biotransformation by Xylaria sp.}

(a) Static culture: Acetophenone $\mathbf{2}$ was dissolved in ethanol and then distributed in 12 Roux bottles after two days' growth. The fermentation was allowed to continue on surface culture for five more days in six of the bottles and for 10 more days in the other six bottles. Chromatography of the extract fermented for five days did not produce any biotransformation product. Chromatography of the extract fermented for 10 days gave $(S)$-1-phenylethanol $(S)$-2a $\left([\alpha]_{\mathrm{D}}^{25}=-5.4\left(\right.\right.$ c $\left.\left.0.8, \mathrm{CHCl}_{3}\right)\right)(6.0 \mathrm{mg})$. (b) Shaken culture: Acetophenone 2 was dissolved in ethanol and then distributed in 10 flasks $(500 \mathrm{~mL})$ in an orbital shaker on a PDB medium after two days' growth. The fermentation was allowed to continue for five more days in five of the flasks and for 10 more days in the other five flasks. Chromatography of the extract fermented for five days did not produce any biotransformation product. Chromatography of the extract fermented for 10 days gave $(S)$-1-phenylethanol $(S)$ 2a $\left([\alpha]_{\mathrm{D}}^{25}=-33.7\left(\right.\right.$ c $\left.\left.0.1, \mathrm{CHCl}_{3}\right)\right)(1.3 \mathrm{mg})$.

\section{References}

1. (a) Schmid, A.; Dordick, J. S.; Hauer, B.; Kiener, A.; Wubbolts, M.; Witholt, B. Nature 2001, 409, 258; (b) Rozell, J. D. Biorg. Med. Chem. 1999, 7, 2253.

2. Alcalde, M.; Ferrer, M.; Plou, F. J.; Ballesteros, A. Trends Biotechnol. 2006, 24 281.

3. Aleu, J.; Bustillo, A. J.; Hernández-Galán, R.; Collado, I. G. Curr. Org. Chem. 2006, 10, 2037.

4. Borges, K. B.; Borges, W. S.; Pupo, M. T.; Bonato, P. S. Appl. Microbiol. Biotechnol. 2007, 77, 669.

5. Schulz, B.; Boyle, C. Mycol. Res. 2005, 109, 661.

6. Mihovilovic, M. D.; Müller, B.; Stanetty, P. Eur. J. Org. Chem. 2002, 3711.

7. Nakamura, K.; Yamanaka, R.; Matsuda, T.; Harada, T. Tetrahedron: Asymmetry 2003, 14, 2659.

8. Miyazawa, M.; Okamura, Sh.; Yamaguchi, M.; Kameoka, H. J. Chem. Technol. Biotechnol. 2000, 75, 143.

9. Ungnade, H. E.; McLaren, A. D. J. Am. Chem. Soc. 1944, 66, 118

10. Demir, A. S.; Ayhan, P.; Sopaci, S. B. Clean: Soil, Air, Water 2007, 35, 406.

11. Seco, J. M.; Quiñoá, E.; Riguera, R. Tetrahedron: Asymmetry 2001, 12, 2915.

12. Prelog, V. Pure Appl. Chem. 1964, 9, 119.

13. Mihovilovic, M. D.; Chen, G.; Wang, S.; Kyte, B.; Rochon, F.; Kayser, M. M.; Stewart, J. D. J. Org. Chem. 2001, 66, 733.

14. Wulff, W. D.; Xu, Y.-C. J. Am. Chem. Soc. 1988, 110, 2312.

15. Naoshima, Y.; Akakabe, Y. Phytochemistry 1991, 30, 3595.

16. Kim, H. S.; Lee, O. K.; Hwang, S.; Kim, B. J.; Lee, E. Y. Biotechnol. Lett. 2008, 30 127.

17. Maier, W.; Hammer, K.; Dammann, U.; Schulz, B.; Strack, D. Planta 1997, 202, 36.

18. Collins, R. P.; Halim, A. F. J. Agric. Food Chem. 1972, 20, 437.

19. Ollis, W. D.; Rey, M. Tetrahedron 1980, 36, 515

20. Masa, A.; Vilanova, M. Food Chem. 2007, 107, 273.

21. Khatib, A.; Wilson, E. G.; Kim, H. K.; Lefeber, A. W. M.; Erkelens, C.; Choi, Y. H.; Verpoorte, R. Anal. Chim. Acta 2006, 559, 264.

22. Sang, S.; Lapsley, K.; Jeong, W.-S.; Lachance, P. A.; Ho, C.-T.; Rosen, R. T. J. Agric Food Chem. 2002, 50, 2459.

23. Dimitriadis, C.; Gill, M.; Harte, M. F. Tetrahedron: Asymmetry 1997, 8, 2153.

24. Collado, I. G.; Aleu, J.; Hernández-Galán, R.; Durán-Patrón, R. Curr. Org. Chem. 2000, 4, 1261. 